ISSN 1392-3196 / e-ISSN 2335-8947

Zemdirbyste-Agriculture, vol. 104, No. 1 (2017), p. 3-8

DOI 10.13080/z-a.2017.104.001

\title{
Organic carbon stock in different types of mineral soils in cropland and grassland in Latvia
}

\author{
Arta BARDULE, Ainars LUPIKIS, Aldis BUTLERS, Andis LAZDINS \\ Latvian State Forest Research Institute "Silava" \\ Rigas 111, Salaspils, Latvia \\ E-mail: arta.bardule@silava.lv
}

\begin{abstract}
Globally, agricultural mineral soils can be either sources or sinks of carbon (C) depending on the land use, environmental conditions and management activities. In Latvia, land use change in cropland and grassland categories, including afforestation and deforestation, are the key sources of greenhouse gas (GHG) emissions. It is requested by the guidelines of the Intergovernmental Panel on Climate Change (IPCC) to use verified scientific methodology and scientifically proven emission factors and data sources in National GHG emission inventory reporting for they key source categories. The scope of the study is to evaluate organic carbon $\left(\mathrm{C}_{\text {org }}\right)$ stock in mineral soil in cropland and grassland in Latvia, where no land use changes were observed for at least 20 years. Remote sensing methods were applied to identify the National Forest Inventory (NFI) plots in grassland and cropland, where no land use changes have taken place since 1990. Vegetation index was used as criteria to validate land use. In total 120 plots on cropland and 120 plots on grassland were randomly selected for soil sampling, and the data on $\mathrm{C}_{\text {org }}$ stock in mineral soil from 218 plots were used in the calculation. Soil samples for physical and chemical analysis from 0-10, 10-20, 20-40 and 40-80 cm depths were collected in 2014 and 2015 . The most widespread soil groups in the studied plots in cropland are Retisols $(21.2 \%)$, Luvisols $(20.8 \%)$ and Stagnosols (18.6\%), but in grassland - Stagnosols (22.8\%), Umbrisols (22.8\%) and Retisols (20.6\%). The mean $\mathrm{C}_{\text {org }}$ stock in soil at 0-40 cm depth in cropland is $83.0 \mathrm{t} \mathrm{ha}^{-1}$, in grassland $-88.6 \mathrm{t} \mathrm{ha}^{-1}$, but the mean $\mathrm{C}_{\mathrm{org}}$ stock in agricultural soils at $0-40 \mathrm{~cm} \mathrm{depth}-85.6 \mathrm{tha} \mathrm{g}^{-1}$. Statistically significant difference between $\mathrm{C}_{\text {org }}$ stock in cropland and grassland was not detected.
\end{abstract}

Key words: agricultural land, land use, organic carbon.

\section{Introduction}

Recognizing the importance of soil organic carbon $\left(\mathrm{C}_{\text {org }}\right)$ for sustaining soil quality and food production, ${ }^{\text {org }}$ the European Union (EU) considers the decline of soil $\mathrm{C}_{\text {org }}$ in European soils as one of the main drivers of soil degradation in its Thematic Strategy for Soil Protection (Commission of the European Communities, 2006; Nocita et al., 2014). Increasing human demands on soil-derived ecosystem services require reliable data on global soil resources for sustainable development (Jandl et al., 2014). Organic matter affects the soil fertility, productivity as well as the different chemical, physical (the formation of soil structure and soil moisture and air regime) and biological properties of soil. Soil organic matter also has several environmental implications such as preventing risk of soil erosion and reducing leaching of nutrients and pesticides to aquatic ecosystems (Jankauskas et al., 2007). Soil organic matter has an essential role in global $\mathrm{C}$ cycle, while $\mathrm{C}$ cycle together with changes of GHG concentration in atmosphere is a significant part of global biochemical cycle (Genxu et al., 2002; FAO, 2004; Heikkinen et al., 2013).

Globally, soils are the largest $\mathrm{C}$ reservoir of the terrestrial systems (FAO, 2004). Agricultural mineral soils can be either sources or sinks of $\mathrm{CO}_{2}$ depending on the land use, environmental conditions and management (Guo, Gifford, 2002; Lal, 2004). Repeated soil monitoring studies in European agricultural lands have shown contrasting trends in $\mathrm{C}$ content. While most studies suggest that the soil $\mathrm{C}$ in mineral soils is decreasing (Goidts, van Wesemael, 2007; Capriel, 2013; Heikkinen et al., 2013), others show no unequivocal trend especially in the last decades (Chapman et al., 2013; Reynolds et al., 2013). The trends in C content can also be contrasting between regions within a country or time periods observed (Heikkinen et al., 2013). Results of Land Use and Land Cover Survey (LUCAS) in EU show large differences of spatial distribution of soil $\mathrm{C}_{\text {org }}$ content mainly in Northern Europe (Tóth et al., 2013). Although a considerable amount of experimental data of soil $\mathrm{C}_{\text {org }}$ stock are available, as well as a local and regional level soil inventories have been done and soil $\mathrm{C}_{\text {org }}$ stock models have been developed, there is a lack of consistent data of $\mathrm{C}_{\text {org }}$ stock in soils in agricultural lands at European level. Even in well-studied regions with a pronounced interest in environmental issues information on soil C is inconsistent (Jandl et al., 2014). In Latvia, soil C stock changes are evaluated in forest soils according to a Level I Forest Health Monitoring Program approach. No significant changes of $\mathrm{C}$ stock in mineral soils have

Please use the following format when citing the article:

Bardule A., Lupikis A., Butlers A., Lazdins A. 2017. Organic carbon stock in different types of mineral soils in cropland and grassland in Latvia. Zemdirbyste-Agriculture, 104 (1): 3-8 DOI 10.13080/z-a.2017.104.001 
been reported up to now (Bārdule, Lazdin̦š, 2010; Lazdin̦š et al., 2013).

Carbon storage in soils mostly is the balance between the input of complicated mixture of dead plant material, soil fauna, root exudates, microbial residues and losses from decomposition and mineralization processes. Movement of $\mathrm{C}$ between the soil and the atmosphere is bidirectional. Under aerobic conditions, most of the $\mathrm{C}$ entering the soil is labile and therefore respired back to the atmosphere through the soil respiration or soil $\mathrm{CO}_{2}$ efflux (FAO, 2004). Consequently, the soil $\mathrm{C}_{\text {org }}$ pool and its loss through emissions have a significant influence on the $\mathrm{CO}_{2}$ concentration in the atmosphere, and thus on global climate change driven by the greenhouse effect (Genxu et al., 2002). Agriculture is considered to be the most intensive land use type due to agricultural harvest, which every year is removed from the land (Haberl et al., 2007) and the intensive cultivation (ploughing), which may increase the C losses from soil (Baker et al., 2007). Many of the factors affecting the flow of $\mathrm{C}$ into and out of soils are affected by land-management practices. Good agricultural practices can enhance soil quality and productivity and increase the amount of C in soils (Lal, 2004).

In this paper we evaluated organic carbon $\left(\mathrm{C}_{\text {org }}\right)$ content and stock in mineral soils in cropland and grassland in Latvia, where no land use changes been had observed for at least 20 years (since 1990).

\section{Materials and methods}

Analysis of normalized difference vegetation index (NDVI) in Landsat satellite image series was applied to identify the National Forest Inventory (NFI) plots on grassland and cropland, where no land use changes took place since 1990. Soil material type (mineral or organic) was diagnosed according to the definitions by WRB (2014) - organic carbon $\left(\mathrm{C}_{\text {org }}\right)$ content in mineral material is $<20 \%$. In total 120 plots on cropland and 120 plots on grassland were randomly selected, but data from 218 plots were used in the calculations of the $\mathrm{C}_{\text {org }}$ stock (Fig. 1).

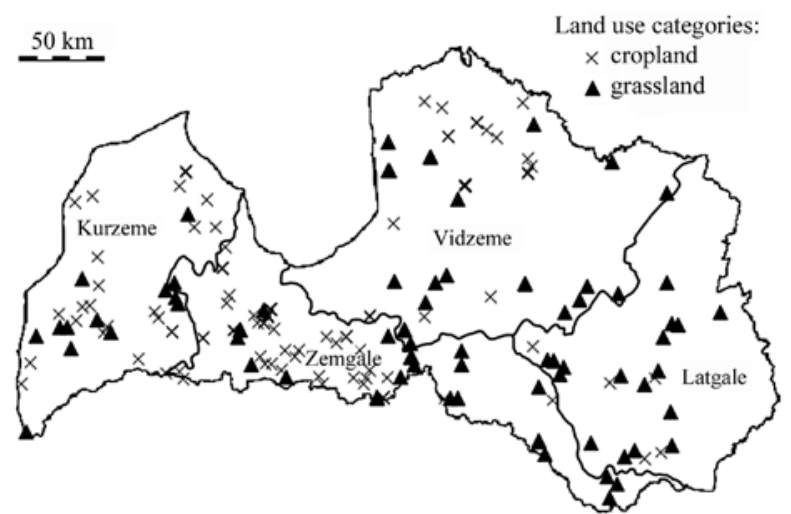

Figure 1. Location of the sampling plots in cropland and grassland in Latvia

Soil sampling was started in autumn (SeptemberNovember) of 2014 and finished in spring (March-April) of 2015. Four sample sets in two repetitions were collected in each sample plot, taking undisturbed soil samples at 0-10, 10-20, 20-40 and 40-80 cm depth using soil sample probes (steel cylinder with a $100 \mathrm{~cm}^{3}$ volume). Allocation of soil sampling sites was representative of the field.

Soil samples were prepared and analyzed in the Forest Environment Laboratory of Latvian State
Forest Research Institute "Silava" according to ISO methodology. Soil samples were prepared for analyses according to the LVS ISO 11464:2005 standard and fine earth fraction of soil ( $\mathrm{D}<2 \mathrm{~mm}$ ) was used for chemical analysis. The following parameters were determined in the soil: dry bulk density (the mass of a unit volume of oven dry soil, the volume includes both solids and pores) according to LVS ISO 11272:1998, total C content using elementary analysis according to LVS ISO 10694:2006, carbonate content using calcimeter according to ISO 10693:1995 and particle size distribution using wet sieving and sedimentation (pipette) method according to ISO 11277:2009. The particle size classes of the fine earth fraction $(\mathrm{D}<2 \mathrm{~mm})$ are defined according FAO (2006) as follows: clay $-<2 \mu \mathrm{m}$, silt $-2-63 \mu \mathrm{m}$ and sand $-63-$ $2000 \mu \mathrm{m}$. Additional analyses were done to determine soil type according to the Latvian Soil Classification system (Kārklinš̌ et al., 2009) and WRB (2015). Soil C stock was calculated according to equation:

$S O C S=S O C \times S B D \times H \times\left(1-P_{2 m m}\right) \times 100^{-1}$,

where SOCS is soil organic carbon stock per unit area, $\mathrm{t} \mathrm{ha}^{-1}$; SOC - organic carbon content in soil, $\mathrm{g} \mathrm{kg}^{-1}$; $\mathrm{SBD}$ - soil bulk density, $\mathrm{kg} \mathrm{m}^{-3} ; \mathrm{H}$ - thickness of the soil layer, $\mathrm{m} ; \mathrm{P}_{2 \mathrm{~mm}}$ - volume fraction of $>2 \mathrm{~mm}$ particles in the soil (assumed to be zero as the value is negligible in most soils), \%. Organic $\mathrm{C}$ stock in soil is calculated for three layers - at 0-20, 0-40 and 0-80 cm depth.

Parametric and nonparametric statistical methods were used to analyse data of soil parameters, normal distribution was tested using package Car (function qqPlot) in program $R$. Statistical differences in soil $\mathrm{C}_{\text {org }}$ content and stock were compared by $T$ test or Wilcoxon rank sum test with continuity correction. We used a $95 \%$ confidence level in all analyses. Data analysis was conducted in program $R$ (R Core Team, 2015) for Linux.

\section{Results and discussion}

Organic carbon $\left(C_{\mathrm{org}}\right)$ content. The mean $\mathrm{C}_{\text {org }}$ content in different layers of soil in cropland and grassland is shown in Table 1. There is no statistically significant difference between $\mathrm{C}_{\text {org }}$ content in soil at $0-10$ and $10-20 \mathrm{~cm}$ depth in cropland and grassland. In deeper $(20-80 \mathrm{~cm})$ soil layers $\mathrm{C}_{\text {org }}$ content is more than twice smaller compared to the topsoil. Statistically significant difference in $\mathrm{C}_{\text {org }}$ content in different soil layers between cropland and grassland was not detected $(p>0.05)$. In 2012, evaluation of soil $\mathrm{C}_{\text {org }}$ in grassland of Natura 2000 protected areas and agrarian lands overgrown with grasses were investigated in Lithuania. Researchers noted that the soil $\mathrm{C}_{\mathrm{org}}$ concentrations decreased with the depth in all treatments, and the highest values were measured at $0-10 \mathrm{~cm}$ soil layer in pre-mainland section of middle reaches of the Nevéžis $\left(76.8 \mathrm{~g} \mathrm{~kg}^{-1}\right)$ and in old seminatural pasture (49.5 $\left.\mathrm{g} \mathrm{kg}^{-1}\right)$ (Liaudanskienè et al., 2013), but Šlepetienè et al. (2013) have reported that the mean soil $\mathrm{C}_{\text {org }}$ at $0-10 \mathrm{~cm}$ soil layer in grasslands in Lithuania rages from $0.73 \%$ in former arable land to $8.31 \%$ in premainland section.

Heikkinen et al. (2013) highlight that the trends in $\mathrm{C}$ content in agricultural soils can be contrasting between regions within a country or time periods observed. In Sweden, Andrén et al. (2008) found that average soil C mass in agricultural soils roughly increases from South to North, since the lower yields and thus $C$ inputs in Northern regions are more than balanced by the higher decomposition rates due to warmer climate in the South. Also our results demonstrate variation of $\mathrm{C}_{\text {rg }}$ content in mineral topsoil ( $0-20 \mathrm{~cm}$ depth) between different regions 
Table 1. Organic carbon $\left(\mathrm{C}_{\text {org }}\right)$ content in different soil layers

\begin{tabular}{cccccc}
\hline \multirow{2}{*}{ Land use } & \multirow{4}{*}{ Values } & \multicolumn{4}{c}{$\mathrm{C}_{\text {org }}$ content $\mathrm{g} \mathrm{kg}^{-1}$} \\
\cline { 3 - 5 } & & $0-10 \mathrm{~cm}$ & $10-20 \mathrm{~cm}$ & $20-40 \mathrm{~cm}$ & $40-80 \mathrm{~cm}$ \\
\hline \multirow{2}{*}{ Cropland } & mean $\pm \mathrm{SE}$ & $21.5 \pm 2.1$ & $20.9 \pm 2.1$ & $10.3 \pm 2.1$ & $2.6 \pm 0.6$ \\
& min-max & $4.6-103.8$ & $5.0-108.8$ & $<0.1-111.8$ & $<0.1-33.6$ \\
& median & 16.4 & 16.6 & 6.4 & 1.8 \\
\hline \multirow{2}{*}{ Grassland } & mean $\pm \mathrm{SE}$ & $27.0 \pm 3.5$ & $23.1 \pm 4.0$ & $9.3 \pm 1.9$ & $9.2 \pm 8.7$ \\
& min-max & $8.1-128.0$ & $2.8-167.3$ & $<0.1-72.5$ & $<0.1-24.6$ \\
& median & 21.7 & 16.1 & 5.6 & 2.0 \\
\hline
\end{tabular}

of Latvia - the highest $\mathrm{C}_{\text {org }}$ content was found in sample plots in Vidzeme and Zemgale, the lowest $\mathrm{C}_{\text {org }}$ content in soil was found in sample plots in Kurzeme and Latgale (Table 2). However, this relates to different distribution of soil types across the country.

The mean $\mathrm{C}_{\text {org }}$ content in mineral soil at $0-20$ $\mathrm{cm}$ depth in cropland is $20.0 \pm 2.8 \mathrm{~g} \mathrm{~kg}^{-1}$, in grassland $-23.6 \pm 5.1 \mathrm{~g} \mathrm{~kg}^{-1}$. In 2009, the European Commission extended the periodic Land Use and Land Cover Survey
(LUCAS) to sample and analyse the main properties of topsoil $(0-20 \mathrm{~cm})$ in 23 Member States of the EU (including 349 sample plots in Latvia). According to the results of LUCAS, the mean soil $\mathrm{C}_{\text {org }}$ content in mineral topsoil $(0-20 \mathrm{~cm})$ in EU was $17.6 \mathrm{~g} \mathrm{~kg}^{-1} \mathrm{C}$ in cropland and $33.4 \mathrm{~g} \mathrm{~kg}^{-1} \mathrm{C}$ in grassland, but in Latvia, the mean soil $\mathrm{C}_{\text {rg }}$ content in mineral topsoil in agricultural soils according to LUCAS was $29.5 \mathrm{~g} \mathrm{~kg}^{-1}$ (Panagos et al., 2013; Tóth et al., 2013; Nocita et al., 2014).

Table 2. Organic carbon $\left(\mathrm{C}_{\text {org }}\right)$ content in soil 0-20 cm depth in different regions of Latvia

\begin{tabular}{ccccc}
\hline Land use & \multicolumn{4}{c}{$\mathrm{C}_{\text {org }}$ content g kg-1 } \\
\hline & Kurzeme & Latgale & Vidzeme & Zemgale \\
\hline Cropland & $17.8 \pm 3.0$ & $14.3 \pm 5.9$ & $22.5 \pm 18.1$ & $22.5 \pm 4.7$ \\
Grassland & $19.9 \pm 5.6$ & $16.3 \pm 2.3$ & $43.6 \pm 34.6$ & $27.3 \pm 10.7$ \\
\hline
\end{tabular}

Organic carbon $\left(C_{\text {org }}\right)$ stock. In cropland and grassland, like in all terrestrial ecosystems, the pool of soil $\mathrm{C}_{\text {org }}$ and changes in this pool over time are determined by the balance between $\mathrm{C}$ input as plant residues and organic amendments, and output resulting from decomposition, erosion and leaching (Akujärvi et al., 2014). Over long periods of time, $\mathrm{C}$ storage in soil varies mainly as a result of climatic, geological and soil-forming factors, whilst over shorter periods of time it is mainly vegetation disturbances or succession, and changes in land use patterns that affect C storage (Batjes, 1996; Lal, 2004).

The mean $\mathrm{C}_{\text {org }}$ stock in different $(0-20,0-40$ and 0-80 cm depth) soil layers in different regions of Latvia is summarized in Table 3 . In the $0-20 \mathrm{~cm}$ layer the largest stores of $\mathrm{C}_{\text {org }}$ were found in Vidzeme and Zemgale. There are no statistically significant differences between grassland and cropland. The mean $\mathrm{C}_{\text {org }}$ stock at $0-20 \mathrm{~cm}$ depth in cropland is $54.6 \pm 5.8 \mathrm{t} \mathrm{ha}^{-1}$, in grassland $58.2 \pm 8.6 \mathrm{t} \mathrm{ha}^{-1}$. Mean $\mathrm{C}_{\text {s }}$ stock at $0-40 \mathrm{~cm}$ depth in mineral soil is $86.3 \pm 6.5 \mathrm{t} \mathrm{ha}^{-1}$. Swedish agricultural land comprises about 3 Mha and its topsoil contains about 270 Mtonnes $\mathrm{C}$ (90 t ha ${ }^{-1} \mathrm{C}, 0-25 \mathrm{~cm}$ depth), but $\mathrm{C}$ mass in arable land is even higher - $94 \mathrm{t} \mathrm{ha}^{-1}$ (Andrén et al., 2008). In Finland, total soil $\mathrm{C}_{\text {org }}$ stock at $0-15 \mathrm{~cm}$ depth in cropland on mineral soils is $117 \mathrm{Tg}$ or $53 \mathrm{t} \mathrm{ha}^{-1}$ (YliHalla et al., 2000).

It has been shown that the vertical distribution of $\mathrm{C}$ in the soil is much deeper than the vertical distribution of roots, suggesting a decrease of soil $\mathrm{C}_{\text {org }}$ decomposition rate with depth (Meersmans et al., 2009). Fontaine et al. (2011) identified the lack of fresh $\mathrm{C}_{\text {org }}$ in deeper soil layers, restricting the energy supply of microbes, as the main cause of reduced decomposition rates at these depths. The largest thickness of soil layer used in characterization of soil $\mathrm{C}_{\text {org }}$ stock within the framework of the agricultural and forest soil monitoring programmes is $80 \mathrm{~cm}$ from the soil top. The mean $\mathrm{C}_{\text {org }}$ stock at $0-80 \mathrm{~cm}$ depth in cropland is $99.1 \pm 11.3 \mathrm{t} \mathrm{ha}^{-1}$, in grassland $102.9 \pm 16.5 \mathrm{tha}^{-1}$, the difference between the mean $\mathrm{C}_{\text {or }}$ stock at $0-80 \mathrm{~cm}$ depth in cropland and grassland is not significant (Table 3 ). In Estonian grassland soils, the mean soil $\mathrm{C}_{\text {org }}$ pool in soil cover is $89 \mathrm{Mg} \mathrm{ha}^{-1}$ in upland mineral soils and $134 \mathrm{Mg} \mathrm{ha}^{-1}$ in lowland mineral soils (Kolli et al., 2007).

Organic C distribution in the soil profile is not homogeneous and is affected by type of vegetation (change in crop rotation and composition), land use and other factors like increase in ploughing depth, manure

Table 3. Organic carbon $\left(\mathrm{C}_{\text {org }}\right)$ stock in the agricultural soils in different regions of Latvia

\begin{tabular}{|c|c|c|c|c|c|}
\hline \multirow{2}{*}{ Land use } & \multicolumn{5}{|c|}{$\mathrm{C}_{\text {org }}$ stock t ha-1 $\mathrm{C}$} \\
\hline & Kurzeme & Latgale & Vidzeme & Zemgale & Mean \\
\hline \multicolumn{6}{|c|}{$0-20 \mathrm{~cm}$ soil layer } \\
\hline Cropland & $49.1 \pm 6.2$ & $41.0 \pm 19.4$ & $56.6 \pm 35.7$ & $60.9 \pm 9.9$ & $54.6 \pm 5.8$ \\
\hline Grassland & $52.5 \pm 10.5$ & $46.1 \pm 5.2$ & $88.1 \pm 58.7$ & $65.3 \pm 18.0$ & $58.2 \pm 8.6$ \\
\hline Mean & $50.2 \pm 5.2$ & $45.2 \pm 4.8$ & $72.3 \pm 30.6$ & $62.4 \pm 8.5$ & $56.2 \pm 4.9$ \\
\hline \multicolumn{6}{|c|}{$0-40 \mathrm{~cm}$ soil layer } \\
\hline Cropland & $77.1 \pm 12.0$ & $65.7 \pm 38.2$ & $87.0 \pm 19.7$ & $88.4 \pm 10.4$ & $83.9 \pm 7.1$ \\
\hline Grassland & $77.4 \pm 15.5$ & $62.6 \pm 9.1$ & $107.8 \pm 31.8$ & $104.8 \pm 26.7$ & $89.4 \pm 12.0$ \\
\hline Mean & $77.2 \pm 9.1$ & $63.1 \pm 8.3$ & $96.3 \pm 17.4$ & $94.2 \pm 11.3$ & $86.3 \pm 6.5$ \\
\hline \multicolumn{6}{|c|}{$0-80 \mathrm{~cm}$ soil layer } \\
\hline Cropland & $92.4 \pm 15.8$ & $77.3 \pm 48.8$ & $95.7 \pm 73.8$ & $108.6 \pm 16.9$ & $99.1 \pm 11.3$ \\
\hline Grassland & $97.2 \pm 19.5$ & $75.6 \pm 12.5$ & $122.2 \pm 90.8$ & $133.5 \pm 42.8$ & $102.9 \pm 16.5$ \\
\hline Mean & $94.0 \pm 11.9$ & $75.9 \pm 11.3$ & $109.0 \pm 50.2$ & $117.1 \pm 17.7$ & $100.8 \pm 9.5$ \\
\hline
\end{tabular}


application (Meersmans et al., 2009). Figure 2 shows the mean cumulative $\mathrm{C}_{\text {org }}$ stock in soils in cropland and grassland. The largest part $(80 \%)$ of $\mathrm{C}_{\text {org }}$ stored in soils is found at $0-40 \mathrm{~cm}$ depth, but $55 \%$ of the $\mathrm{C}_{\text {org }}$ is stored in the arable layer $(0-20 \mathrm{~cm})$. Consequently, soll cultivation has direct impact on about $50 \%$ of $\mathrm{C}_{\text {org }}$ stored in soils. Batjes (1996) studied relative distribution of $\mathrm{C}_{\mathrm{oro}}$ as a function of depth and found that on average, 39-70\% of the total $\mathrm{C}_{\mathrm{org}}$ in the upper $100 \mathrm{~cm}$ of mineral soil is held in the first $30 \mathrm{~cm}$, and $58-81 \%$ - in the first $50 \mathrm{~cm}$.

The results show no statistically significant difference in $\mathrm{C}_{\text {org }}$ stock in different soil groups between cropland and grassland (Table 4). Largest $\mathrm{C}_{\text {org }}$ stock is in Anthrosols, Gleysols and Phaeozems in grassland, but those soil groups are not widely distributed in studied plots - total occurrence in the studied plots is less than $7 \%$ both in cropland and grassland, consequently, due

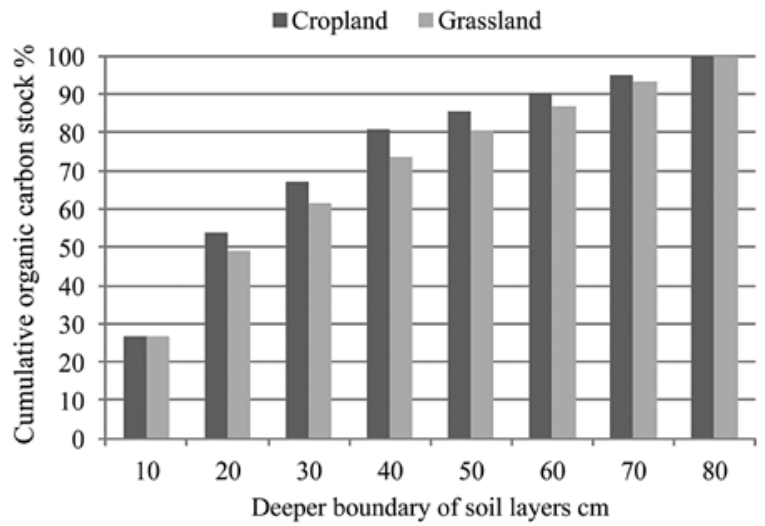

Figure 2. The mean distribution of organic carbon $\left(\mathrm{C}_{\text {org }}\right)$ stock in soil profile in cropland and grassland

Table 4. Organic carbon $\left(\mathrm{C}_{\text {org }}\right)$ stock in the different soil types

\begin{tabular}{|c|c|c|c|c|c|c|c|c|}
\hline \multirow{3}{*}{ Soil group } & \multirow{2}{*}{\multicolumn{2}{|c|}{$\begin{array}{c}\text { Soil group occurrence } \\
\text { in the studied plots } \\
\%\end{array}$}} & \multicolumn{6}{|c|}{$\mathrm{C}_{\text {org }}$ stock $\mathrm{t} \mathrm{ha}^{-1} \mathrm{C}$} \\
\hline & & & \multicolumn{2}{|c|}{ 0-20 cm soil layer } & \multicolumn{2}{|c|}{$0-40 \mathrm{~cm}$ soil layer } & \multicolumn{2}{|c|}{$0-80 \mathrm{~cm}$ soil layer } \\
\hline & cropland & grassland & cropland & grassland & cropland & grassland & cropland & grassland \\
\hline Retisols & 21.2 & 20.6 & $71.4 \pm 5.1$ & $56.8 \pm 4.1$ & $98.9 \pm 4.0$ & $88.2 \pm 3.4$ & $146.0 \pm 16.3$ & $97.0 \pm 6.2$ \\
\hline Anthrosols & 0.0 & 1.8 & - & $73.4 \pm 27.9$ & - & $143.6 \pm 52.8$ & - & $322.0 \pm 141.8$ \\
\hline Arenosols & 2.2 & 0.9 & $31.0 \pm 8.2$ & $71.8 \pm 6.2$ & $70.1 \pm 13.3$ & $104.2 \pm 27.4$ & $64.5 \pm 18.3$ & $121.1 \pm 29.9$ \\
\hline Cambisols & 13.4 & 15.8 & $42.1 \pm 1.4$ & $41.2 \pm 1.8$ & $59.0 \pm 2.5$ & $58.4 \pm 3.2$ & $72.4 \pm 3.4$ & $75.5 \pm 5.2$ \\
\hline Gleysols & 0.7 & 2.6 & $79.2 \pm 9.1$ & $158.8 \pm 5.4$ & $122.0 \pm 45.2$ & $208.2 \pm 22.9$ & $129.5 \pm 52.5$ & $205.0 \pm 6.2$ \\
\hline Luvisols & 20.8 & 11.0 & $47.9 \pm 4.3$ & $52.7 \pm 3.8$ & $76.2 \pm 3.0$ & $81.7 \pm 9.8$ & $86.8 \pm 9.9$ & $105.5 \pm 22.3$ \\
\hline Phaeozems & 5.9 & 1.8 & $75.1 \pm 6.2$ & $81.7 \pm 12.0$ & $104.9 \pm 7.2$ & $124.3 \pm 20.8$ & $133.4 \pm 11.6$ & $155.8 \pm 19.1$ \\
\hline Planosols & 2.2 & 0.0 & $68.8 \pm 11.9$ & - & $104.6 \pm 12.0$ & - & $135.0 \pm 15.7$ & - \\
\hline Stagnosols & 18.6 & 22.8 & $47.1 \pm 3.5$ & $55.5 \pm 3.7$ & $73.0 \pm 3.0$ & $88.3 \pm 4.3$ & $75.6 \pm 5.8$ & $81.1 \pm 6.6$ \\
\hline Umbrisols & 14.9 & 22.8 & $64.3 \pm 6.0$ & $72.7 \pm 8.3$ & $101.3 \pm 10.5$ & $96.1 \pm 4.1$ & $116.5 \pm 11.9$ & $129.9 \pm 11.5$ \\
\hline
\end{tabular}

to limited data those soil groups cannot be considered as main soil $\mathrm{C}_{\text {org }}$ accumulators in grassland and cropland in Latvia. In Estonian grassland soils, the main soil $\mathrm{C}_{\text {o }}$ accumulators are Sapric Histosols, Histic Gleysols, Cambisols and Luvisols, but soil $\mathrm{C}_{\text {org }}$ sequestration capacity rages from $24 \pm 8 \mathrm{Mg} \mathrm{ha}^{-1}$ in Salic Fluvisols to $338 \pm 77 \mathrm{Mg} \mathrm{ha}^{-1}$ in Sapric Histosols (Kolli et al., 2007).

Comparison of $\mathrm{C}_{\text {rr }}$ stock in the different soil texture classes represented in croplands and grasslands is shown in Table 5. There are no statistically significant difference in $\mathrm{C}_{\text {org }}$ stock in different soil texture classes between cropland and grassland. In several plots, significant bigger $\mathrm{C}_{\text {org }}$ stock is found in soils with the clay loam and loamy sand texture. All of these plots are located on semi-hydromorphic soils confirming the assumption that the hydrological regime has significant impact on $\mathrm{C}_{\text {org }}$ stock in soil. The relation between soil $\mathrm{C}_{\mathrm{rg}}$ and drainage status of the soil is in agreement with other studies, reporting a general increase of soil $\mathrm{C}$ with increasing soil wetness (Liebens, VanMolle, 2006; Meersmans et al., 2009; 2011).

Table 5. Organic carbon $\left(\mathrm{C}_{\text {org }}\right)$ stock at $0-20 \mathrm{~cm}$ depth in the different soil texture classes $(\mathrm{FAO}, 2006)$ in cropland and grassland

\begin{tabular}{|c|c|c|c|c|}
\hline \multirow[t]{2}{*}{ Soil texture classes } & \multicolumn{2}{|c|}{$\begin{array}{l}\text { Soil texture classes occurrence } \\
\text { in the studied plots } \%\end{array}$} & \multicolumn{2}{|c|}{$\mathrm{C}_{\text {org }}$ stock $\mathrm{t} \mathrm{ha}^{-1} \mathrm{C}$} \\
\hline & cropland & grassland & cropland & grassland \\
\hline Clay loam & 5.2 & 4.8 & $41.8 \pm 1.5$ & $98.6 \pm 30.0$ \\
\hline Loam & 31.2 & 36.8 & $59.7 \pm 6.1$ & $68.0 \pm 14.6$ \\
\hline Loamy sand & 3.9 & 3.2 & $50.9 \pm 6.4$ & $51.8 \pm 21.7$ \\
\hline Sand & 1.3 & 1.6 & $31.0 \pm 8.2$ & $42.5 \pm 14.3$ \\
\hline Sandy clay loam & 0.0 & 3.2 & - & $68.9 \pm 30.8$ \\
\hline Sandy loam & 40.3 & 44.0 & $51.9 \pm 3.6$ & $60.0 \pm 7.3$ \\
\hline Silt loam & 11.7 & 4.8 & $61.2 \pm 9.3$ & $53.9 \pm 4.3$ \\
\hline Silt clay & 1.3 & 0.0 & $82.5 \pm 6.4$ & - \\
\hline Silty clay loam & 5.2 & 1.6 & $70.9 \pm 10.6$ & $93.5 \pm 19.1$ \\
\hline
\end{tabular}

Moreover, Fullen et al. (2007) highlight that topsoil samples show low correlation between soil organic matter and texture because topsoils contain plant residues in different stages of decomposition, while subsoil organic matter consists mostly of specific humic substances.

Considering the uncertainty of $\mathrm{C}_{\text {org }}$ stock in semi-hydromorphic soil, we excluded from calculations indicators that exceeded 2 standard error intervals and recalculated the mean $\mathrm{C}_{\text {org }}$ stock at $0-40 \mathrm{~cm}$ depth.
According to these calculations, the mean $\mathrm{C}_{\text {org }}$ stock in cropland is $83.0 \pm 5.4 \mathrm{t} \mathrm{ha}^{-1}$, in grassland $-88.6 \pm$ $7.8 \mathrm{t} \mathrm{ha}^{-1}$. The difference between the $\mathrm{C}_{\text {org }}$ stock in soils in grassland and cropland is not significant. The mean $\mathrm{C}_{\text {org }}$ stock in mineral soil is $85.6 \pm 4.6 \mathrm{t} \mathrm{ha}^{-1}$.

According to the study results, there is no substantiation to calculate accumulation of $\mathrm{C}_{\text {org }}$ in mineral soils due to land use change from cropland to grassland, as well as the $\mathrm{CO}_{2}$ emissions from mineral soil due to land use change from grassland to cropland, as far as the NFI 
data are used to estimate land use changes. The obtained results do not describe the impact of management activities (like mowing and biomass extraction without compensation on nutrients by fertilization) in a particular field. However, the established network of the NFI plots is useful to monitor soil $\mathrm{C}_{\text {org }}$ at a national level.

In most of the studies concerning the $\mathrm{C}$ exchange between soil and atmosphere only the topsoil $(0-0.3 \mathrm{~m})$ is taken into account (Meersmans et al., 2009). According to Tier 1 methodology of IPCC Guidelines for National Greenhouse Gas Inventories and using default emission factors (2006 IPCC Guidelines...), C stock in soil at $0-30 \mathrm{~cm}$ depth in cropland in Latvia could vary from $94.4 \mathrm{tha}^{-1}$ (areas on fertile loam and clay soils, where manure is used regularly) to $58.7 \mathrm{t} \mathrm{ha}^{-1}$ (areas where manure is not used), but in grassland - from 95 to $71 \mathrm{t} \mathrm{ha}^{-1}$. According to the study results, calculated mean $\mathrm{C}_{\text {ro }}$ stock in soil at $0-30 \mathrm{~cm}$ depth in cropland is about $70 \mathrm{tha}^{-1}$, but in grassland $-79 \mathrm{t} \mathrm{ha}^{-1}$ (the difference is not significant). Organic C stock in soil in both land use types is in the range proposed by the IPCC Guidelines.

\section{Conclusions}

1. According to the results of the study, the mean organic carbon $\left(\mathrm{C}_{\mathrm{org}}\right)$ content at $0-20 \mathrm{~cm}$ depth in mineral soil in cropland is $20.0 \pm 2.8 \mathrm{~g} \mathrm{~kg}^{-1}$, grassland $-23.6 \pm$ $5.1 \mathrm{~g} \mathrm{~kg}^{-1}$; the mean $\mathrm{C}_{\text {org }}$ content in agricultural soils in Latvia is $21.7 \pm 2.7 \mathrm{~g} \mathrm{~kg}^{-1}$. Relatively higher $\mathrm{C}_{\text {org }}$ content in topsoil is found in Zemgale and Vidzeme regions, which is the result of uneven distribution of soil types. There is no significant difference between the $\mathrm{C}_{\text {org }}$ content in topsoil compared to LUCAS data; however, LUCAS seems to overestimate $\mathrm{C}$ content in soil.

2. This study shows that the $80 \%$ of $\mathrm{C}_{\text {org }}$ stored in agricultural soils is at $0-40 \mathrm{~cm}$ depth. Consequently, the top $40 \mathrm{~cm}$ is selected to characterize soil $\mathrm{C}_{\text {org }}$ stock in grassland and cropland in Latvia. The results indicate that mean soil $\mathrm{C}_{\text {org }}$ stock at $0-40 \mathrm{~cm}$ depth in cropland is $83.9 \pm 7.1 \mathrm{t} \mathrm{ha}^{-1}$, while in grassland $-89.4 \pm 12.0 \mathrm{t} \mathrm{ha}^{-1}$. If the extreme values of $\mathrm{C}$ stock in semi-hydromorphic soils are excluded from calculation, the mean soil $\mathrm{C}_{\text {org }}$ stock at $0-40 \mathrm{~cm}$ depth in cropland reduces to $83.0 \stackrel{\text { org }}{ \pm}$ $5.4 \mathrm{t} \mathrm{ha}^{-1}$ and in grassland - to $88.6 \pm 7.8 \mathrm{t} \mathrm{ha}^{-1}$, but the mean $\mathrm{C}_{\text {org }}$ stock at $0-40 \mathrm{~cm}$ depth is $85.6 \pm 4.6 \mathrm{tha}^{-1}$. The results of the study indicate that there are no significant difference between soil $\mathrm{C}_{\text {org }}$ stock in grassland and cropland. This is mainly due to the dynamic changes in land use over the past decades and significant impact of extensively cultivated arable land on the $\mathrm{C}$ accumulation rates. Furthermore, accumulation of $\mathrm{C}_{\text {or }}$ in agricultural lands can be promoted by the deterioration of technical conditions of drainage systems.

3. According to the study results, soil $\mathrm{C}_{\text {org }}$ stock changes should not be accounted in the Land Use, LandUse Change and Forestry (LULUCF) sector when the land use change from cropland to grassland or vice versa are estimated by the National Forest Inventory (NFI), because there is not statistically significant difference between soil $\mathrm{C}_{\text {org }}$ stock in these land use categories.

4. The results indicate that the most widespread mineral soil groups in agricultural land in Latvia are Retisols, Stagnosols and Umbrisols, but the largest $\mathrm{C}_{\text {org }}$ stock is found in Anthrosols, Gleysols and Phaeozems in grassland, although those soil groups are not widely distributed in the studied plots.

\section{Acknowledgements}

The study is done within the scope of the EEA grants project "Evaluation of carbon stock in cropland and grassland" (No. 10942).

Received 01082016 Accepted 14112016

\section{References}

Akujärvi A., Heikkinen J., Palosuo T., Liski J. 2014. Carbon budget of Finnish croplands - effects of land use change from natural forest to cronland. Geoderma Regional, 2-3: 1-8 https://doi.org/10.1016/j.geodrs.2014.09.003

Andrén O., Kätterer T., Karlsson T., Eriksson J. 2008. Soil C balances in Swedish agricultural soils 1990-2004, with preliminary projections. Nutrient Cycling in Agroecosvstems. 81 (2): 129-144 https://doi.org/10.1007/s10705-008-9177-z

Baker J. M., Ochsner T. E., Venterea R. T., Griffis T. J. 2007. Tillage and soil carbon sequestration - what do we really know? Agriculture, Ecosystems and Environment, 118: 1-5 https://doi.org/10.1016/j.agee.2006.05.014

Bārdule A., Lazdiņš A. 2010. Accumulation of carbon and nitrogen in mineral soils in grey alder (Alnus incana (L.) Moench) stands on naturally afforested farmlands. Mežzinātne, 21 (54): 95-109 (in Latvian)

Batjes N. H. 1996. Total C and N in the soils of the world. Euronean Journal of Soil Science, 47: 151-163 https://doi.org/10.1111/j.1365-2389.1996.tb01386.x

Capriel P. 2013. 'Irends in organic carbon and nitrogen contents in agricultural soils in Bavaria (south Germany) between 1986 and 2007. Euronean Journal of Soil Science, 64 (4): 445-454 https://doi.org/10.1111/ejss.12054

Chapman S. J., Bell J. S., Campbell C. D., Hudson G., Lilly A., Nolan A. J., Robertson A. H. J., Potts J. M., Towers W. 2013. Comparison of soil carbon stocks in Scottish soils between 1978 and 2009. Euronean .Journal of Soil Science, 64 (4): 455-465 https://doi.org/10.1111/ejss. 12041

Commission of the European Communities. 2006. Communication from the Commission to the Council, the European Parliament, the European Economic and Social Committee and the Committee of the Regions - Thematic Strategy for Soil Protection

FAO. 2004. Carbon sequestration in dry land soils. Food and Agriculture Organization of the United Nations, World soil resources reports No. 102

FAO. 2006. Guidelines for soil description. Rome, Food and Agriculture Organization of the United Nations, $97 \mathrm{p}$.

Fontaine S., Henault C., Aamor A., Bdioui N., Bloor J. M. G. Maire V., Mary B., Revaillot S., Maron P. A. 2011. Fungi mediate long term sequestration of carbon and nitrogen in soil through their priming effect. Soil Biology and Biochemistry. 43 (1): 86-96 https://doi.org/10.1016/j.soilbio.2010.09.017

Fullen M. A., Jankauskas B., Jankauskienè G., Booth C. A., Šlepetienè A. 2007. Inter-relationships between soil texture and soil organic matter content in eroded Eutric Albeluvisols in Lithuania. Žemès ūkio mokslai, 14 (3): 9-1

Genxu W., Ju Q., Guodong C., Yuanmin L. 2002. Soil organic carbon pool of grassland soils on the Qinghai-Tibetan Plateau and its global implication. Science of the Total Environment. 291 (1-3): 207-217 https://doi.org/10.1016/S0048-9697(01)01100-7

Goidts E., van Wesemael B. 2007. Regional assessment of soil organic carbon changes under agriculture in Southern Belgium (1955-2005). Geoderma. 141 (3-4): 341-354 https://doi.org/10.1016/j.geoderma.2007.06.013

Guo L. B., Gifford R. M. 2002. Soil carbon stocks and land use change: a meta analvsis. Global Change Biologv. 8 (4): 345-360 https://doi.org/10.1046/j.1354-1013.2002.00486.x

Haberl H., Erb K. H., Krausmann F., Gaube V., Bondeau A., Plutzar C., Gingrich S., Lucht W., Fischer-Kowalski M. 2007. Quantifying and mapping the human appropriation of net primary production in earth's terrestrial ecosystems. Proceedings of the National Academy of Sciences of the United States of America, 104 (31): 12942-12947 https://doi.org/10.1073/pnas.0704243104 
Heikkinen J., Ketoja E., Nuutinen V., Regina K. 2013. Declining trend of carbon in Finnish cropland soils in 1974-2009. Global Change Biology, 19 (5): 1456-1469 https://doi.org/10.1111/gcb.12137

2006 IPCC Guidelines for National Greenhouse Gas Inventories. Agriculture, Forestry and other Land Use, vol. 4

Jandl R., Rodeghiero M., Martinez C., Cotrufo M. F., Bampa F., van Wesemael B., Harrison R. B., Guerrini I. A., deB Richter Jr. D., Rustad L., Lorenz K., Chabbi A., Miglietta F. 2014. Current status, uncertainty and future needs in soil organic carbon monitoring. Science of the Total Environment. 468-469: 376-383 https://doi.org/10.1016/j.scitotenv.2013.08.026

Jankauskas B., Jankauskienė G., Fullen M. A. 2007. Relationships between soil organic matter content and soil erosion severity in Albeluvisols of the Žemaičiai Uplands. Ekologija, 53 (1): 21-28

Kārkliņš A., Gemste I., Mežals H., Nikodemuss O., Skujāns R. 2009. Latvijas augšnu noteicējs. Jelgava, Latvijas Lauksaimniecības Universitāte, 235 p. (in Latvian)

Kolli R., Koster T., Kauer K. 2007. Organic matter of Estonian grassland soils. Agronomy Research, 5 (2): 109-122

Lal R. 2004. Agricultural activities and the global carbon cycle. Nutrient Cycling in Agroecosystems, 70 (2): 103-116 https://doi.org/10.1023/B̈:FRES.0000048480.24274.0f

Lazdiņš A., Bārdule A., Stola J., Krišāns O. 2013. Temporary carbon stock changes in forest soil in Latvia. Interdisciplinary research for higher socioeconomic value of forests. Riga, Latvia, p. 51-52

Liebens J., VanMolle M. 2006. Influence of estimation procedure on soil organic carbon stock assessment in Flanders, Belgium. Soil Use and Management, 19 (4): 364-371 https://doi.org/10.1111/j.1475-2743.2003.tb00327.x

Liaudanskienè I., Slepetienè A., Šlepetys J., Stukonis V. 2013. Evaluation of soil organic carbon stability in grasslands of protected areas and arable lands applying chemodestructive fractionation. Zemdirbyste-Agriculture, 100 (4): 339-348 https://doi.org/10.13080/z-a.2013.100.043

Meersmans J., Van Wesemael B., De Ridder F., Fallas Dotti M., De Baets S., Van Molle M. 2009. Changes in organic carbon distribution with depth in agricultural soils in northern Belgium, 1960-2006. Global Change Biology, 15(11): 2739-2750

https://doi.org/10.1111/j.1365-2486.2009.01855.x

Meersmans J., van Wesemael B., Goidts E., Van Molle M. De Baets S., De Ridder F. 2011. Spatial analysis of soil organic carbon evolution in Belgian croplands and grasslands, 1960-2006. Glohal Change Biolnov. 17: 466-479 https://doi.org/10.1111/j.1365-2486.2010.02183.x

Nocita M., Stevens A., Ioth G., Panagos P., van Wesemael B., Montanarella L. 2014. Prediction of soil organic carbon content by diffuse reflectance spectroscopy using a local partial least square regression approach. Soil Biology and Biochemistry, 68: 337-347 https://doi.org/10.1016/j.soilbio.2013.10.022

Panagos P., Ballabio C., Yigini Y., Dunbar M. B. 2013. Estimating the soil organic carbon content for European NUTS2 regions based on LUCAS data collection. Science of the Total Environment. 442: 235-246 https://doi.org/10.1016/j.scitotenv.2012.10.017

Reynolds B., Chamberlain P. M., Poskitt J., Woods C., Scott W. A., Rowe E. C., Robinson D. A., Frogbrook Z. L., Keith A. M., Henrys P. A., Black H. I. J., Emmett B. A. 2013. Countryside survey: national "Soil change" 1978 2007 for topsoils in Great Britain - acidity, carbon, and total nitrogen status. Vadose Zone Journal, 12 (2) https://doi.org/10.2136/vzj2012.0114

Šlepetienė A., Liaudanskienè I., Šlepetys J., Stukonis V., Jokubauskaite I. 2013. Soil carbon, nitrogen and phosphorus distribution in grassland systems, important for landscape and environment. Journal of Environmental Fngineering and I andscane Management 21 (4): 263-272 https://doi.org/10.3846/16486897.2013.830973

Tóth G., Jones A., Montanarella L. 2013. LUCAS topsoil survey. European Commission, Joint Research Centre, Institute for Environment and Sustainability

Yli-Halla M., Mokma D. L., Peltovuori T., Sippola J. 2000. Agricultural soil profiles in Finland and their classification. Jokioinen, Finland, $70 \mathrm{p}$.

WRB. 2014. World Reference Base for Soil Resources 2014, update 2015. International soil classification system for naming soils and creating legends for soil maps. World Soil Resources Reports No. 106. FAO, Rome, 203 p.

ISSN 1392-3196 / e-ISSN 2335-8947

Zemdirbyste-Agriculture, vol. 104, No. 1 (2017), p. 3-8

DOI 10.13080/z-a.2017.104.001

\title{
Organinės anglies kiekis Latvijos dirbamose žemėse ir žolynuose
}

\author{
A. Bardule, A. Lupikis, A. Butlers, A. Lazdins \\ Latvijos valstybinis miškininkystès institutas "Silava"
}

\section{Santrauka}

Pasauliniu mastu mineraliniai žemės ūkio paskirties dirvožemiai, priklausomai nuo žemėnaudos, aplinkos sąlygų ir agrotechnikos, gali būti arba anglies (C) šaltiniai, arba sankaupos. Latvijoje žemėnaudos pakeitimas ariamų ir žolynų dirvožemių kategorijose, taip pat ir želdinimas mišku bei miško iškirtimas, yra pagrindiniai šiltnamio efektą sukeliančių dujų emisijos šaltiniai. Tarpvyriausybinès klimato kaitos grupès gairès reikalauja taikyti moksliškai pagrịstas metodologijas ir moksliškai ịrodytus emisijos veiksnius bei duomenų šaltinius iš Nacionalinio šiltnamio efektą sukeliančių dujų emisijos aprašo, ịvardijančio pagrindines šaltinių kategorijas. Tyrimu siekta įvertinti organinès anglies $\left(\mathrm{C}_{\mathrm{org}}\right)$ atsargas Latvijos mineraliniame dirvožemyje, kuriame auginti žemès ūkio augalai ir žolynai, žemėnaudos nekeičiant mažiausiai 20 metų. Nustatant Nacionalinio miškų registro laukelius žolynuose ir ariamame dirvožemyje, kuriame žemėnauda nebuvo keičiama nuo 1990 m., buvo taikyti nuotolinio stebejjimo metodai. Kaip žemėnaudos patvirtinimo kriterijus buvo naudotas augmenijos indeksas. Dirvožemio mėginiai paimti iš 120 ariamo dirvožemio laukelių ir 120 žolynų laukelių, pasirinktų atsitiktine tvarka, o skaičiavimams naudoti $\mathrm{C}_{\text {org }}$ atsargų iš 218 mineralinio dirvožemio laukelių duomenys. Dirvožemio ėminiai fizikinėms ir cheminėms savybẻms nustatyti 2014 ir $2015 \mathrm{~m}$. buvo paimti iš 0-10, 10-20, 20-40 ir 40-80 cm gylio. Tirtuose ariamo dirvožemio laukeliuose labiausiai paplitusios dirvožemio grupès buvo Retisol (21,2\%), Luvisol (20,8 \%) ir Stagnosol (18,6\%), o žolyno dirvožemyje - Stagnosol (22,8 \%), Umbrisol (22,8 \%) ir Retisol (20,6\%). Vidutinès C $\mathrm{org}_{\text {atsargos } 0-40}$ $\mathrm{cm}$ gylyje dirvožemio, kuriame auginti žemès ūkio augalai, buvo $83,0 \mathrm{tha}^{-1}$, žolynų dirvožemyje šrgame gylyje $\mathrm{C}_{\mathrm{org}}$ atsargos sudare $88,6 \mathrm{t} \mathrm{ha}^{-1}, \mathrm{o} \mathrm{C}_{\text {org }}$ atsargos žemės ūkyje naudojamo dirvožemio 0-40 $\mathrm{cm}$ gylyje buvo $85,6 \mathrm{tha}^{-1}$. Esminio skirtumo tarp $\mathrm{C}_{\text {org }}$ atsargų dirvožemyje, kuriame auginti žemès ūkio augalai, ir žolynų dirvožemio nebuvo nustatyta.

Reikšminiai žodžiai: organinė anglis, žemėnauda, žemès ūkio paskirties žemė. 